\title{
Leachability and Microstructural Analysis of Clay and Lime Stabilized/Solidified Polluted Sediment - Long-Term Performance
}

\author{
Djurdja Kerkez ${ }^{*}$, Dunja Radjenović1, Dragana Tomašević Pilipović ${ }^{1}$, Milena Bečelić-Tomin ${ }^{1}$ \\ Nataša Slijepčević1, Srđan Rončević', Božo Dalmacija' \\ ${ }^{1}$ Faculty of Sciences, Department for Chemistry, Biochemistry and Environmental Protection, University of Novi Sad, \\ Trg Dositeja Obradovića 3, 21000 Novi Sad, Serbia \\ *Corresponding author, e-mail: djurdja.kerkez@dh.uns.ac.rs
}

Received: 03 November 2018, Accepted: 22 March 2019, Published online: 09 May 2019

\begin{abstract}
The objective of this study is to enable a better understanding of the effectiveness of solidification/stabilization (S/S) technique in treating polluted sediment, and provide the much needed validation of the longevity of the technology. In this research kaolinite and montmorillonite, with a certain proportion of lime, were used for S/S treatment of sediment polluted with metals. Leachability of metals was examined using the toxicity characteristic leaching procedure (TCLP) and the German standard leaching test (DIN 3841-4 S4) prescribed in national legislative. Results indicated successful S/S treatment using both clays and lime, from the aspect of all leached metals even with $\mathrm{pH}$ variations over time and slight changes in structural integrity of specimens. X-ray diffraction (XRD), scanning electron microscope (SEM) analyses and porosity measurement were also performed on the prepared monolithic matrices. XRD qualitative and semi-quantitative analysis proved hydration and pozzolanic product formation with increase in their content and finer crystallites formation over time. SEM analysis confirmed the presence of morphologically dense and stable structures while pore size distribution indicated on mesoporous matrices with ongoing compaction over time. Generally, structural microanalysis indicated the formation of hardened matrices over time and hydration process has been fully completed and further carbonation took place. Unconfined compressive strength measurement gave the satisfying results and matured monolite with $30 \%$ of montmorillonite and $10 \%$ of lime can be considered potentially applicable as non-load-bearing material. In summary, all results indicated that this kind of S/S treatment can achieve satisfactory durability and represent reliable and economically feasible technique for long-term remediation of metal polluted sediment.
\end{abstract}

Keywords

solidification/stabilization, clays, metal polluted sediment, long-term treatment performance, microstructural analysis

\section{Introduction}

Stabilization/solidification $(\mathrm{S} / \mathrm{S})$ technologies are widely used for treatment of hazardous wastes that are mostly inorganic and contaminated soils and sediments before their final disposal [1-3]. Wang et al. [3] used Portland cement, lime and coal fly ash for heavy metal polluted sediment, while Tomasevic et al. [2] used fly ash in combination with kaolinite for $\mathrm{Ni}$ and $\mathrm{Zn}$ polluted sediment. Modified zeolite effectively stabilized $\mathrm{Pb}, \mathrm{Cu}, \mathrm{Zn}$ and $\mathrm{Cd}$ in lake sediment to different extents [4]. Stabilization of $\mathrm{Cu}, \mathrm{Zn}, \mathrm{Cd}, \mathrm{Hg}, \mathrm{Cr}$ and $\mathrm{As}$ in soil using modified bentonites was performed by $\mathrm{Yu}$ et al. [5]. Bentonites manifested distinct immobilization effectiveness towards various metals, proving that main interactive mechanisms proceeded via cation exchange, but also via physical adsorption and partitioning, Additionally, Liu et al. [6] reported satisfying $\mathrm{S} / \mathrm{S}$ treatment of heavy metal contaminated soils, and further investigated different influences on treatment efficiency. These technologies use different immobilization agents in treating waste due to their ability to provide chemical stability and physical strength. Suitable binding agents are selected for specific areas and contaminants based on a set of criteria, which are mainly dependent on the characteristics of the end products as well as the set goals and possibilities. The commonly used binders include Portland cement, lime, pulverized fuel ash (PFA) and clays [7-10]. Lime (CaO) as the main stabilizing agent is used as it is cheaper than cement and calcium hydroxide and the heat of hydration results in an increased 
reaction rate. After adding calcium oxide to contaminated sediment, as with cement, three immobilization mechanisms are possible: chemical incorporation, encapsulation and sorption, or most common precipitation, inclusion or sorption [11-12]. Clays and modified clays, containing additives for the control of clay hydration, can be used for the treatment of waste as secondary agents. Chemical stabilization is due to adsorption, chemisorption or incorporation into the crystalline structure of the mineral agent. Clays play an important role in the environment because they represent the natural "sponge" of pollutants, binding their cations through ion exchange or adsorption. These ions can be replaced relatively easily without affecting the mineral structure of the clay. Large specific surface, chemical and mechanical stability, layered structure, high cation exchange capacity and other properties make clay excellent adsorbents [13]. Kaolinite and montmorillonite are the two most commonly used clays for adsorption of metals but also other pollutants [14]. The applications of kaolinite, $\left(\mathrm{Si}_{4}\right)^{\mathrm{IV}}\left(\mathrm{Al}_{4}\right)^{\mathrm{VI}} \mathrm{O}_{10}(\mathrm{OH})_{8}$, a widely used industrial clay raw material, depend on its surface reactivity. The main mineral component consists of layers held together via H-bonds. Each layer consists of a two-dimensional arrangement of Al-centered octahedral and a two-dimensional arrangement of Si-centered tetrahedral [15-16]. Montmorillonite $\left(\mathrm{Si}_{7.8} \mathrm{Al}_{0.2}\right)^{\mathrm{IV}}\left(\mathrm{Al}_{3.4} \mathrm{Mg}_{0.6}\right)^{\mathrm{VI}} \mathrm{O}_{20}(\mathrm{OH})_{4}$ consists of two tetrahedral structures with a central aluminum octahedral grid. The tetrahedron and octahedral grids are combined so that the edges of the tetrahedron of each silicon grid and one of the octahedral structures of the hydroxide form a common envelope. The atoms in this envelope that are common to both grids are oxygen ions [14]. The concrete-montmorillonite interactions, and more general, concrete-clay interactions, have been studied as part of the expected geochemical reactions occurring within the composite engineered barriers in highlevel radioactive waste in deep geological repositories.

However, long-term effectiveness of $\mathrm{S} / \mathrm{S}$ treatment is essential in addressing issues related to the strength, the buffering capacity, and the leachability of S/S treated materials and it is used to validate the remediation process and hence convince stakeholders of its longevity [17]. Hence, it is very important to understand the contaminant immobilization mechanisms involved in the binding within $\mathrm{S} / \mathrm{S}$ materials so as to further improve this technique.

The long-term result of such interactions has to be evaluated in order to tackle the impact on the mineralogical and physical-chemical properties at the interface of both materials that could compromise their safety functions in the long-term [18-19].

The effectiveness of the long-term chemical performance of $\mathrm{S} / \mathrm{S}$ treatments is usually assessed using batch leaching tests. Batch leaching tests with a single extraction are the preferred choice for regulatory assessment due to their simplicity, improved reproducibility, and shorter time requirements. Serbian legislative also uses the Toxicity Characteristic Leaching Procedure - TCLP and DIN 3841-4 S4 complementary procedure for the evaluation of waste characteristics.

In this study sediment samples were collected from the Great Backi Canal (Vojvodina, Serbia). The canal began to be more intensively polluted at the end of the 20th century. Most of the industries discharged untreated or partially treated wastewater into the canal. The total organic pollution from industry is $36.6 \mathrm{t} \mathrm{COD/day} \mathrm{or} 17.9 \mathrm{tBOD}_{5} /$ day and from municipal wastewaters $1329 \mathrm{~kg} C O D /$ day or $619 \mathrm{~kg} \mathrm{BOD} /$ day. Due to the high pressure from the wastewaters in the canal, along a $6 \mathrm{~km}$ stretch about $400,000 \mathrm{~m}^{3}$ of sediment has been formed. The canal is about $3 \mathrm{~m}$ deep, with the sediment varying in depth from 1 to $2.5 \mathrm{~m}$, depending upon the point of wastewater discharge [20].

The main study objectives can be summarized as follows: (1) characterization and classification of sediment from Great Backa Canal from the aspect of metal content, (2) defining S/S treatment of polluted sediment with the addition of clays and lime, (3) evaluation of the long-term effectiveness of $\mathrm{S} / \mathrm{S}$ treatment by assessing the leaching potential and environmental impact based on the different leaching procedures TCLP and DIN 3841-4 S4, after different periods of maturation ( 7 and 28 days and 7 years), (4) microstructural analyses including X-ray diffraction (XRD) and scanning electron microscopy (SEM) to assist with the chemical speciation of the metals, (4) specific surface area and porosity characterization of treated samples and unconfined compressive strength measurement.

\section{Materials and methods}

Sediment composite sample was taken from Great Backa Canal. The Great Backa Canal represents the main artery of the whole hydrosystem in Backa, Serbia. Today, Great Backa Chanal represents an ecological black spot due to the concentration of pollutants, both in water and sediment.

In this paper two types of clay minerals and lime were used for $\mathrm{S} / \mathrm{S}$ treatment of polluted sediment. Kaolinite was obtained from Sigma-Aldrich, Germany, and montmorillonite from Bento product d.o.o. Sipovo, Bosnia 
and Herzegovina. Lime was purchased from lime factory Zagradje, RTB Bor, Serbia. Chemical composition of used immobilization agents is presented in Table 1.

The pseudo-total metal content of the sediment was determined in a dried sediment sample, by using aqua regia - $\left(\mathrm{HCl}: \mathrm{HNO}_{3}=3: 1\right)$, digested by the EPA 3051a [21] microwave digestion method (Milestone, Star E). Then the samples were analyzed by flame AAS technique (Perkin Elmer AAnalyst ${ }^{\mathrm{TM}}$ 700) on the total metal content in accordance with the procedure EPA 7000B [22].

The pseudo-total metal content, representing the sum of acid-soluble, reducible, oxidizable and residual fraction [23], in the native sediment sample is shown in Table 2 and the quality of the sediment is compared with the values prescribed in Regulation on limit values of pollutants in surface and groundwater and sediment and deadlines for their achievement ("Official Gazette RS". 50/2012) [24].

This regulation includes several numerical values among which target and remediation value. The target value is a lower value, the basic concentration below which is known or assumed that the element/compound does not affect the natural characteristics of the sediment.

Table 1 Chemical composition of immobilization agents used for $\mathrm{S} / \mathrm{S}$ treatment

\begin{tabular}{lccc}
\hline & \multicolumn{3}{c}{ used for S/S treatment } \\
\hline & Kaolin & Montmorillonite & Lime \\
\cline { 2 - 4 } & & $\%$ & \\
$\mathrm{SiO}_{2}$ & 45.9 & 58.9 & $/$ \\
$\mathrm{Al}_{2} \mathrm{O}_{3}$ & 37.2 & 22.7 & $/$ \\
$\mathrm{Fe}_{2} \mathrm{O}_{3}$ & 3.34 & 4.83 & $/$ \\
$\mathrm{MgO}$ & 1.40 & 1.40 & $/$ \\
$\mathrm{CaO}$ & 0.250 & 1.85 & 99.0 \\
$\mathrm{~K}_{2} \mathrm{O}$ & 0.140 & 0.240 & $/$ \\
$\mathrm{Na}$ & $\mathrm{O}$ & 0.120 & $/$ \\
Loss of ignition & 11.7 & 9.96 & $/$ \\
\hline
\end{tabular}

The remediation value is a higher value, the maximum tolerable concentration above which remediation is requested. In assessing the quality of sediment, the values for standard sediment are translated into values for the actual sediment based on a certain content of organic matter (measured as a lost percentage of mass after volatilization, calculated over a dry mass of sediment) and clay content (mass percentage of particles smaller than $2 \mathrm{~mm}$ ). Correction of analytically determined metal concentrations was performed in order to be able to determine the sediment class according to the national legislation, because the quality criteria are given for standard sediment with $10 \%$ of organic matter and $25 \%$ of clay. Using the mathematical model developed by DHV (Dwars, Heederik and Verhey), the metal concentrations were first corrected to the standard sediment and then classified according to the national regulations. Finally, the quality of the sediment was determined based on the parameter that was in the worst, highest category, as the model foresees. The results shown in Table 2 indicate that polluted sediment corresponds to 4 or $4+$ class in relation to the tested metals and needs remediation.

\subsection{S/S treatment}

$\mathrm{S} / \mathrm{S}$ treatment was performed by mixing dried sediment $\left(105^{\circ} \mathrm{C}\right)$ with appropriate immobilization agents: kaolinite, montmorillonite and lime. Specimens were designated by the capital letters K: kaolinite, M: montmorillonite, and L: lime, followed by a number representing percent weight of the given attribute. The S/S agent content was expressed as percentage of the total solids weight. K30L10 sample was prepared using $30 \%$ of kaolinite and $10 \%$ of lime and M30L10 sample using $30 \%$ of montmorillonite and $10 \%$ of lime.

Samples were prepared in the form of monolithic cubes $((3 \pm 0.1) \times(3 \pm 0.1) \times(3 \pm 0.1) \mathrm{cm})$ by compaction

Table 2 Results of pseudo total metal content with classification according to Regulation on limit values of pollutants in surface and groundwater and sediment and deadlines for their achievement (“Official Gazette RS". 50/2012)

\begin{tabular}{|c|c|c|c|c|c|}
\hline \multirow[t]{2}{*}{ Metals } & Measured value & Corrected value & Target value & Remediation value & $\begin{array}{c}\text { Classification according to } \\
\text { parameter }\end{array}$ \\
\hline & \multicolumn{5}{|c|}{ mgkg-1 $^{-1}$} \\
\hline $\mathrm{Cr}$ & 771.8 & 1335 & 100 & 380 & 4 \\
\hline $\mathrm{Ni}$ & 416.6 & 1048 & 35 & 210 & $4^{+}$ \\
\hline $\mathrm{Cu}$ & 415.7 & 506.9 & 36 & 190 & 4 \\
\hline $\mathrm{Zn}$ & 1291 & 1962 & 140 & 720 & 4 \\
\hline $\mathrm{Cd}$ & 29.20 & 26.85 & 0.8 & 12 & 4 \\
\hline $\mathrm{Pb}$ & 1969 & 2255 & 85 & 530 & $4^{+}$ \\
\hline
\end{tabular}

Class 0 - natural level in sediment, Class 1 - slightly polluted sediment, Class 2 - moderate pollution, Class 3 - heavily contaminated sediment; Class $4(4+)$ - extremely polluted sediment 
at optimum water content, defined as the water content at which the sediment can be compacted to the maximum dry unit weight using modified compactive effort. Typically, cohesive soils and sediments at the optimum water content can be squeezed into a lump that barely sticks together when hand pressure is released, but will break cleanly into two sections when "bent". The compaction was performed according to ASTM D1557-00 [25], providing a compactive effort of $2700 \mathrm{kNm} \mathrm{m}^{-3}$. Samples were cured at $20^{\circ} \mathrm{C}$ in sealed sample bags and after 7 (7D) and 28 days (28D) subjected to the different leaching tests and further characterization. Mixtures were then left to mature. Maturation was performed in controlled laboratory conditions, leaving the mixtures in contact with air for seven years (7Y). In this way more relevant environmental conditions, over much longer timescales, can be tested. After this period matured mixtures were tested in same manner.

\subsection{Leaching tests}

\subsubsection{TCLP test (Toxicity Characteristic Leaching Procedure)}

TCLP tests include the extraction of the waste material from $100 \mathrm{~g}$ sample placed in a 2-liter extraction vessel and mixed with the extraction fluid. Initial tested $\mathrm{pH}$ of the sample leachate was $\leq 5$, so the extraction fluid \# 1 (5.7 $\mathrm{ml}$ glacial acetic acid and $64.3 \mathrm{ml}$ of $1 \mathrm{~N} \mathrm{NaOH}$ in 1 liter of water, $\mathrm{pH}=4.93 \pm 0.05$ ) was used. The samples were extracted at a liquid to solid (L/S) ratio of 20:1 in capped polypropylene bottles on a rotary tumbler at $30 \mathrm{rpm}$ for $18 \mathrm{~h}$. After 18 hours of stirring, the $\mathrm{pH}$ was measured in the extract which was filtered after that through a membrane $(0.45 \mu \mathrm{m})$ filter [26]. The filtrate was then preserved with nitric acid and then was analyzed for metal content by using AAS (Perkin Elmer AAnalyst ${ }^{\mathrm{TM}}$ 700) technique according to USEPA Method 7000B [22], (2007) and USEPA Method 7010 [27].

\subsubsection{The German standard leaching test - DIN 3841-4 S4 (DIN 3841-4 S4; 1984)}

The German standard leaching test - DIN 3841-4 S4, uses grained sample with particle size smaller than $10 \mathrm{~mm}$ [28]. Leaching is performed with deionized water at 10:1 L/S ratio (1 kg-1), during the testing period of $24 \mathrm{~h}$. After shaking the final $\mathrm{pH}$ value was measured and a sample was filtered through a membrane $(0.45 \mathrm{um})$ filter. After that, the filtrate was preserved with nitric acid and then was analyzed for metal content by using AAS (Perkin Elmer
AAnalyst ${ }^{\mathrm{TM}}$ 700) technique. Measurement of the $\mathrm{pH}$ values was carried out using a $\mathrm{pH}$ meter inoLab $\mathrm{pH} / \mathrm{ION}$ 735 (WTW GmbH, Germany).Pseudo-total metal content determination and leaching tests were applied to every sample in triplicate. Mean values were used and the RSDs $(n=3)$ were below $5 \%$.

\subsection{Sample characterization}

To better understand metal immobilization and other micro structural properties, X-ray diffraction (XRD) and scanning electron microscope (SEM) analyses were performed on the prepared monolithic matrices.

For XRD analysis samples were powdered in agate mortar and placed onto carrier-glass plate which has rectangular recess of $20 \times 20 \mathrm{~mm}$ and a depth of $0.5 \mathrm{~mm}$. Equipment used for XRD is an automatic diffractometer Rigaku MiniFlex 600, Brag-Brentano geometry with secondary graphite monochromator. Radiation is from the copper anode, the voltage on the pipe is $40 \mathrm{kV}$, and the current is $15 \mathrm{~mA}$. Recording is performed in step mode, the step retention time is $2 \mathrm{~s}$, and the step is 0.03 degrees. Semi-qualitative $\mathrm{XRD}$ analysis as well as crystallite size of the components using the Scherrer method was performed using HighScore Plus software, PANalytical, the Netherlands.

For SEM measurement the monolithic matrices were crushed and dried, ground to powder and then subjected to analyses. SEM photographs were carried out by QUANTAX 70 EDS System TM3000 - Bruker, Germany.

The Brunauer-Emmett-Teller (BET) specific surface area, pore volume, and pore size were determined based on the adsorption and desorption isotherms of $\mathrm{N}_{2}$ at $77 \mathrm{~K}$ obtained on an Autosorb iQ Surface Area Analyzer (Quantachrome Instruments, USA). The samples were outgassed at $110{ }^{\circ} \mathrm{C}$ for approximately $5 \mathrm{~h}$ before running isotherms. Mesopore volume were derived from desorption isotherms using the BJH (Barrett-Joyner-Halenda) model. Micropore volumes were additionally calculated using t-test and the Horwath-Kawazoe (HK) method. The total pore volume and average pore radius were derived from the amount of vapor adsorbed at a relative pressure close to unity, by assuming that the pores are then filled with liquid adsorbate. Non-Local Density Functional Theory (NLDFT) was used for pore size distribution analysis.

To validate the applicability of the designed waste mixture, mechanical performance of the obtained monolites was measured in terms of uniaxial compressive strength. Compressive strength was determined by using a penetrometer which measures the penetration resistance of 
undisturbed samples in $\mathrm{kPa}$. The results are interpreted according to [29-30]. Also, the compressive strengths were compared with ASTM Standards for non-load-bearing [31] and load-bearing [32] concrete masonry units, respectively.

\section{Results and discussion}

\subsection{Leaching tests}

TCLP is one example of a field mimicking test that is applied as a screening protocol in practice. The field conditions adopted by TCLP are those of an assumed "mismanagement" scenario described as disposal of hazardous waste in a biologically active municipal solid waste landfill. This test is specifically designed to mimic the acidic conditions of the sanitary landfill, as well as to identify wastes that have the potential to contaminate groundwater. In national legislative, according to the Regulation on categories, testing and classification of waste ("Official Gazette RS”. 56/2010) [33], TCLP procedure prescribes parameters and limit values for testing of toxic characteristic of waste intended for disposal. The results of TCLP test on treated samples are presented in Table 3. Cr, Ni, $\mathrm{Cu}$ and $\mathrm{Zn}$ showed lower leaching after 28 days from $\mathrm{S} / \mathrm{S}$ treatment applied followed by slight increase after 7 years. $\mathrm{Cd}$ showed constant decrease in leaching and $\mathrm{Pb}$ leaching increased in 28 days and then decreased over long period of time. These slight changes can be attributed to $\mathrm{pH}$ variations and consequently metal solubility over time. Generally, the leached concentrations of metals, from both specimens, in all tested periods, are far below the limit values according to "Official Gazette RS", 56/2010 [33],

Table 3 Leached metal concentrations according to TCLP procedure

\begin{tabular}{|c|c|c|c|c|c|c|c|}
\hline \multirow{2}{*}{ Samples } & \multirow{2}{*}{$\mathrm{pH}$} & $\mathrm{Cr}$ & $\mathrm{Ni}$ & $\mathrm{Cu}$ & $\mathrm{Zn}$ & $\mathrm{Cd}$ & $\mathrm{Pb}$ \\
\hline & & \multicolumn{6}{|c|}{$\mathrm{mgl}^{-1}$} \\
\hline \multirow[t]{2}{*}{ Sediment } & 5.3 & 22.7 & 47.28 & 28.34 & 248.6 & 1.151 & 5.782 \\
\hline & & \multicolumn{6}{|c|}{$7 \mathrm{D}$} \\
\hline K30L10 & 9.6 & 0.025 & 1.429 & 0.178 & 4.111 & 0.107 & 0.068 \\
\hline \multirow[t]{2}{*}{ M30L10 } & 8.7 & 0.020 & 0.149 & 0.105 & 0.127 & 0.011 & 0.013 \\
\hline & & \multicolumn{6}{|c|}{$28 \mathrm{D}$} \\
\hline K30L10 & 8.4 & 0.034 & 1.139 & 0.087 & 2.775 & 0.093 & 0.117 \\
\hline \multirow[t]{2}{*}{ M30L10 } & 7.9 & 0.025 & 0.809 & 0.047 & 1.579 & 0.080 & 0.063 \\
\hline & & \multicolumn{6}{|c|}{$7 \mathrm{Y}$} \\
\hline K30L10 & 7.7 & 0.093 & 2.903 & 1.548 & 4.194 & 0.022 & 0.015 \\
\hline M30L10 & 7.1 & 0.049 & 2.488 & 1.187 & 2.825 & 0.021 & 0.259 \\
\hline $\begin{array}{l}\text { Limit } \\
\text { values* }\end{array}$ & & 5 & 20 & 25 & 250 & 1 & 5 \\
\hline
\end{tabular}

* Limit values for metals according to TCLP procedure and they stayed relatively stable over time. Therefore, it can be concluded that these materials do not do not posse toxic properties and can be considered safe and non-hazardous for disposal.

DIN 3841-4 S4 test is a standard batch leaching test, which has been widely used for regulatory compliance purposes in Germany and Austria, as well as for general assessment elsewhere. In national legislation it prescribes parameters for testing wastes and leachate from inert, non-hazardous or hazardous waste landfills. In Table 4 leached metal concentrations, for both specimens over time, according to DIN 3841-4 S4 test are presented. In both specimens after 7 days only $\mathrm{Ni}$ and $\mathrm{Cu}$ leached in noticeable concentrations. After 28 days, leaching started to decrease, probably due to pozzolanic reactions. Testing after period of seven years showed good stability of tested specimens. Again $\mathrm{Ni}$ and $\mathrm{Cu}$ leached in greater concentrations. When interpreting results by using the national regulations for the testing and classification of waste, as well as by comparing it with the values prescribed by the European Union [34], from the aspect of Cr, Zn, Cd and $\mathrm{Pb}$ specimens are characterized as inert waste and can be used in specific purposes. From the aspect of $\mathrm{Ni}$ and $\mathrm{Cu}$, specimens are considered as non-hazardous waste.

Generally, leached metal concentrations greatly declined compared to untreated sediment sample. Differences in metal leaching between these two tests are the sum of several factors. Used acid, in TCLP test, can complex metals causing them to leach in greater concentrations [35]. Additionally, solid/liquid ratio is different for each test.

Table 4 Leached metal concentrations according to DIN 3841-4 S4 test

\begin{tabular}{|c|c|c|c|c|c|c|c|}
\hline \multirow{2}{*}{ Samples } & \multirow{2}{*}{$\mathrm{pH}$} & $\mathrm{Cr}$ & $\mathrm{Ni}$ & $\mathrm{Cu}$ & $\mathrm{Zn}$ & $\mathrm{Cd}$ & $\mathrm{Pb}$ \\
\hline & & \multicolumn{6}{|c|}{$\mathrm{mgkg}^{-1}$} \\
\hline \multirow[t]{2}{*}{ Sediment } & 7.1 & 74.53 & 52.68 & 34.58 & 148.7 & 6.117 & 84.65 \\
\hline & & \multicolumn{6}{|c|}{$7 \mathrm{D}$} \\
\hline K30L10 & 11.3 & 0.760 & 4.940 & 58.70 & 0.730 & 0.001 & 0.040 \\
\hline \multirow[t]{2}{*}{ M30L10 } & 9.7 & 0.770 & 2.170 & 38.70 & 0.460 & 0.001 & 0.020 \\
\hline & & \multicolumn{6}{|c|}{$28 \mathrm{D}$} \\
\hline K30L10 & 10.2 & 0.359 & 2.849 & 6.014 & 1.376 & 0.007 & 0.068 \\
\hline \multirow[t]{2}{*}{ M30L10 } & 8.9 & 0.292 & 0.631 & 0.398 & 0.859 & 0.003 & 0.031 \\
\hline & & \multicolumn{6}{|c|}{$7 \mathrm{Y}$} \\
\hline K30L10 & 8.5 & 0.560 & 8.600 & 17.069 & nd & nd & nd \\
\hline M30L10 & 7.4 & 0.120 & 3.899 & 22.170 & 0.320 & 0.003 & nd \\
\hline $\mathrm{A}^{*}$ & & 0.5 & 0.4 & 2 & 4 & 0.04 & 0.5 \\
\hline $\mathrm{B}^{*}$ & $>6$ & $10-70$ & $10-40$ & $50-100$ & $50-200$ & $1-5$ & $10-50$ \\
\hline
\end{tabular}

A*- Maximum allowed concentration of accepting waste as inert L/ $\mathrm{S}=10\left(\mathrm{lkg}^{-1}\right)$; $\mathrm{B}^{*}$ - Maximum allowed concentration of accepting waste as non-hazardous $\mathrm{L} / \mathrm{S}=10\left(\mathrm{lkg}^{-1}\right)$; nd-not detected 
Finally, $\mathrm{pH}$ greatly differs, as TCLP uses citric acid and DIN3841-4 S4 uses deionized water as leaching fluid. This has the impact on final $\mathrm{pH}$ of the leachate after the test. $\mathrm{pH}$ value has influence on clay surface. As the surface of clay is more protonated at low $\mathrm{pH}, \mathrm{H}^{+}$competes with metal ion resulting in active sites less able to retain heavy metal ions, this may be explained by the surface complexation reactions which are influenced by the electrostatic attraction between negatively charged groups at clay surface and the metal ions [36]. For both tests it can be seen that $\mathrm{pH}$ values decreased with the increasing incubation period, most likely due to the reaction between alkaline $\mathrm{CaO}$ and $\mathrm{CO}_{2}$ to form $\mathrm{CaCO}_{3}$ as time proceeded [37]. Lowering the $\mathrm{pH}$ over time may hindered the binding of some positively charged metal ions. Namely, observing metal hydroxide solubility as a function of $\mathrm{pH}$ value, it can be expected that metal leach in lower $\mathrm{pH}$ region [38]. So, metal leaching can be observed as a balance between pozzolanic product formation (metal immobilization) and metal precipitation and dissolution as a result of $\mathrm{pH}$ variation. Also, presence of ettringite implies that there is the physical damage resulting from the formation of expansive minerals. Both the physical damage and the crystals may be caused by desiccation. This also can lead to increase metal leaching over time [39].

\subsection{Chemical, mineralogical and structural characterization}

XRD analysis was performed on native sediment sample and K30L10 and M30L10 specimens after 7, 28 days and 7 years (Fig. 1) as well as semi-quantitative analysis (Table 5).

Main crystalline phases identified, in native sediment sample, were quartz $\left(\mathrm{SiO}_{2}\right)$, muscovite $\mathrm{KAl}_{2}\left(\mathrm{AlSi}_{3} \mathrm{O}_{10}\right)$ $(\mathrm{F}, \mathrm{OH})_{2}$, enstatite $\left(\mathrm{MgSiO}_{3}\right)$, dolomite $\mathrm{CaMg}\left(\mathrm{CO}_{3}\right)_{2}$, calcite $\left(\mathrm{CaCO}_{3}\right)$ and illite $\left(\mathrm{K}, \mathrm{H}_{3} \mathrm{O}\right)(\mathrm{Al}, \mathrm{Mg}, \mathrm{Fe})_{2}(\mathrm{Si}, \mathrm{Al})_{4} \mathrm{O}_{10}[(\mathrm{O}$ $\left.\mathrm{H})_{2},\left(\mathrm{H}_{2} \mathrm{O}\right)\right]$. In solidified specimens the main peak was quartz originating from sediment, and alumosilicates present both in sediment and used clays as mineralogy is depended on site specific conditions [40].

X-ray diffraction analyses of sediment mixtures with clays and lime indicated that pozzolanic product formation did take place within the 28-d curing period as calcium silicate hydrate $(\mathrm{CSH})$ and calcium silicate hydroxide $\left(\mathrm{CSH}^{*}\right)$ were the identified products. The reaction product formed is initially a non-crystalline gel, but eventually becomes calcium silicate hydrate, $\mathrm{C}-\mathrm{S}-\mathrm{H}$, and due to its surface area it represents a principle mineral phase for adsorption of
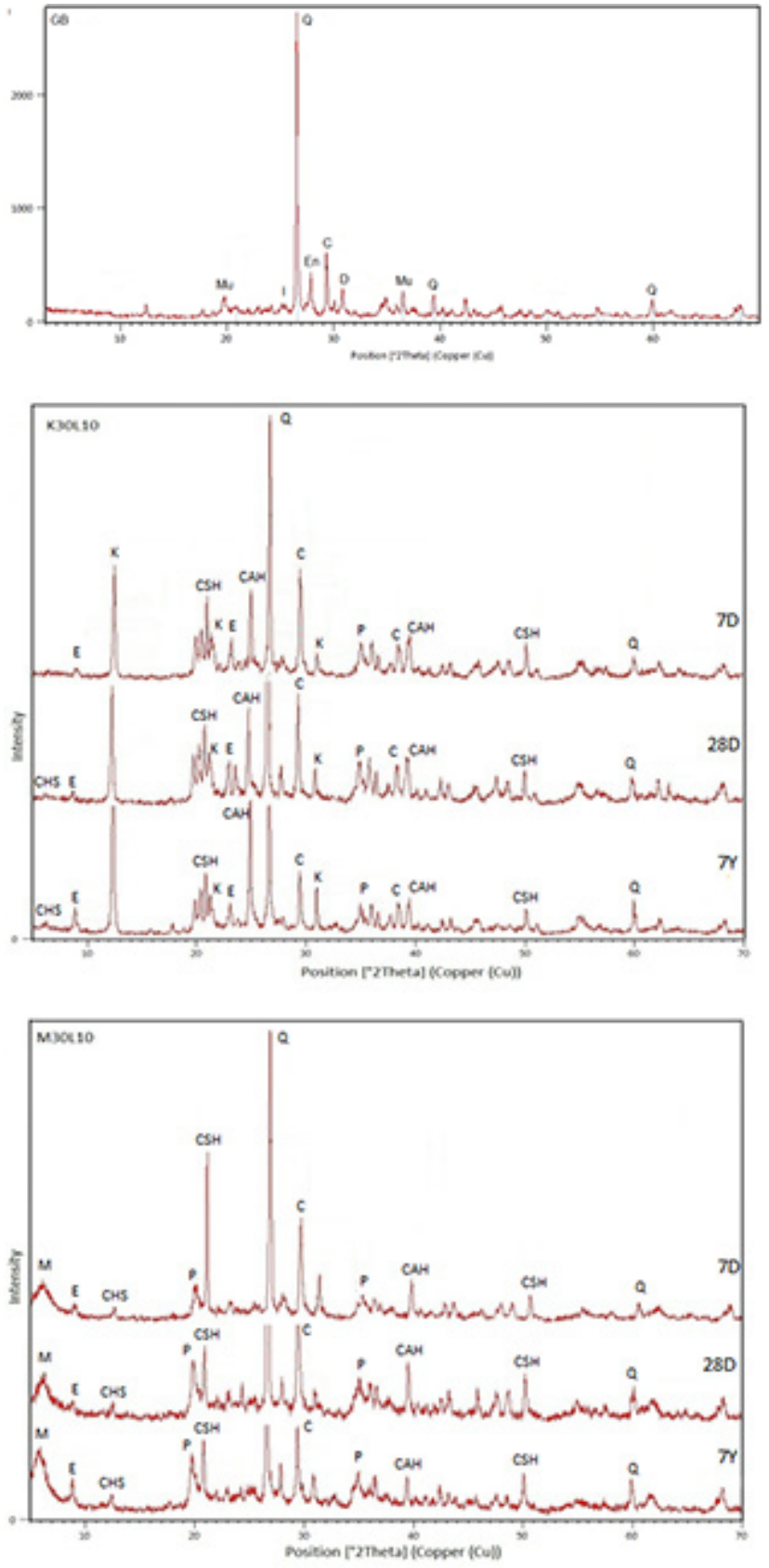

Fig. 1 X-ray diffraction analysis (XRD) applied on S/S specimens a) native sediment sample; b) K30L10 and c) M30L10 after 7, 28 days and 7 years, where the following products are identified: Q-quartz, Enenstatite, Mu-muscovite, D-dolomite, I-illite, C-calcite, K-kaolinite, $\mathrm{M}$-montmorillonite, E-ettringite, $\mathrm{CAH}$-calcium aluminat hydrate, $\mathrm{CSH}$ calcium silicate hydrate, CHS-calcium hydroxide silicate, P-portlandite

metal cations [39]. In general, however, these reactions are slower than those of cement and do not produce exactly the same products in terms of chemical and physical properties. Formation of calcite is a result of atmospheric carbonation of portlandite $\left(\mathrm{Ca}(\mathrm{OH})_{2}\right)$ over time, proving that $\mathrm{S} / \mathrm{S}$ treated sediment is metastable [17]. Portlandite presence 
Table 5 Semi-quantitative analysis by XRD

\begin{tabular}{|c|c|c|c|c|c|c|c|}
\hline \multirow{3}{*}{ Component } & \multirow{2}{*}{ Sediment } & \multicolumn{3}{|c|}{ K30L10 } & \multicolumn{3}{|c|}{ M30L10 } \\
\hline & & $7 \mathrm{D}$ & $28 \mathrm{D}$ & $7 \mathrm{Y}$ & $7 \mathrm{D}$ & $28 \mathrm{D}$ & $7 \mathrm{Y}$ \\
\hline & \multicolumn{7}{|c|}{$\%$} \\
\hline Muscovite & 13 & / & l & / & I & l & / \\
\hline Illite & 9 & / & / & / & l & l & / \\
\hline Enstatite & 16 & l & l & l & / & I & / \\
\hline Dolomite & 14 & / & / & / & / & l & / \\
\hline Montmorillonite & l & l & l & / & 10 & 10 & 11 \\
\hline $\begin{array}{l}\text { Calcium hydroxide } \\
\text { silicate }\end{array}$ & I & 0 & 8 & 10 & 8 & 9.8 & 11 \\
\hline Ettringite & l & 8 & 10 & 12 & 7 & 10 & 12 \\
\hline Kaolinite & / & 23.3 & 14 & 16 & / & l & I \\
\hline $\begin{array}{l}\text { Calcium silicate } \\
\text { hydrate }\end{array}$ & l & 8 & 9 & 8.5 & 10 & 11.2 & 12.7 \\
\hline Quartz & 37 & 29.6 & 20 & 17 & 34 & 22 & 16.3 \\
\hline Calcite & 11 & 15 & 17 & 13 & 12 & 15 & 16 \\
\hline Portlandite & I & 6.1 & 7 & 6.5 & 12 & 14 & 15 \\
\hline $\begin{array}{l}\text { Calcium aluminat } \\
\text { hydrate }\end{array}$ & l & 10 & 15 & 17 & 7 & 8 & 6 \\
\hline
\end{tabular}

also indicated that hydration processes were not fully completed after 28 days, and that reactions are still take place in direction of pozzolanic product formation, which results in better metal immobilization and structural integrity of solidified materials. Even after 7 years there are portlandite peaks present, in both specimens, due to lime used for the treatment [41-42]. Also, small peak of ettringite $\left(3 \mathrm{CaO} \cdot \mathrm{Al}_{2} \mathrm{O}_{3} \cdot \mathrm{CaSO}_{4} \cdot 32 \mathrm{H}_{2} \mathrm{O}\right)$ was recorded at $2 \theta$ value of $\sim 9$ degrees, which becomes more pronounced over time.
Ettringite formation can result in monolite expansion and damage [43]. In general, the formation of pozzolanic components, as well as the presence of calcite and portlandite, further confirms that these matrices have good potential in use as structural materials [29]. By XRD a direct measurement of the mineralogical composition of samples can be performed, but only the relative masses of the mineral phases reported to the crystallized fraction of the sample can be determined [44]. From the semi-quantitative analysis it can be seen that the main mineral phase in $\mathrm{S} / \mathrm{S}$ specimens is quartz. Calcium hydroxide silicate, calcium silicate hydrates and calcium aluminat hydrate content is slightly changed and intensified over time. Portlandite is present in all specimens over time with significant amount in M30L10 mixtures. Similar case is with the presence of calcite whose content increases especially within the first 28 days of curing. Obvious increase in ettringite content is evident over time as one of main pozzolanic reaction products. Crystallite sizes determined for selected reflections from the direct application of the Scherrer equation are presented in Table 6. Coherently reflecting domains, better known as crystallites, can have different size and shape. The average size of these crystallites can be estimated from the broadening of (X-ray or neutron) diffraction reflections via Scherrer equation. As the crystallite size increases, its contribution to the observed peak width becomes smaller. It is also important to note that if crystals have different unit cell dimensions (perhaps from slight compositional differences among different crystals as opposed to compositional gradients within a given crystal), this will result in

Table 6 Crystallite dimensions determined from Scherrer analyses

\begin{tabular}{|c|c|c|c|c|c|c|c|}
\hline \multirow{3}{*}{ Component } & \multirow{2}{*}{ Sediment } & \multicolumn{3}{|c|}{ K30L10 } & \multicolumn{3}{|c|}{ M30L10 } \\
\hline & & $7 \mathrm{D}$ & $28 \mathrm{D}$ & $7 \mathrm{Y}$ & $7 \mathrm{D}$ & $28 \mathrm{D}$ & $7 \mathrm{Y}$ \\
\hline & \multicolumn{7}{|c|}{ Crystallite size $(\AA)$} \\
\hline Muscovite & 235.9 & / & / & / & l & l & 1 \\
\hline Illite & 325.7 & l & I & l & l & l & l \\
\hline Enstatite & 477.6 & / & l & l & l & l & l \\
\hline Dolomite & 385.9 & l & l & I & l & l & l \\
\hline Montmorillonite & / & l & l & l & 79.36 & 79.51 & 85.48 \\
\hline Calcium hydroxide silicate & / & l & 333.7 & 532.7 & 284.8 & 303.5 & 281.04 \\
\hline Ettringite & / & 183.3 & 228.6 & 368.3 & 318.1 & 326.4 & 394.4 \\
\hline Kaolinite & / & 322.2 & 367.6 & 323.5 & l & l & / \\
\hline Calcium silicate hydrate & / & 473.9 & 577.7 & 444.02 & 423.9 & 708.9 & 337.5 \\
\hline Quartz & 446.3 & 404.1 & 407.9 & 463.4 & 367.4 & 422.04 & 355.3 \\
\hline Calcite & 431.1 & 322.4 & 309.6 & 414.4 & 289.7 & 286.9 & 332.5 \\
\hline Portlandite & / & 270.2 & 209.5 & 353.6 & 135.2 & 159.2 & 287.5 \\
\hline Calcium aluminat hydrate & / & 396.9 & 335.8 & 416.5 & 356.7 & 333.8 & 307.1 \\
\hline
\end{tabular}


peak broadening as well [45]. Crystallite sizes of used clays did not differ significantly over time.

Calcium hydroxide silicate and calcium silicate hydrate crystals increased in period of 28 days of curing, but latter decreased in a small extent, while calcium aluminate hydrate crystallites sizes did not vary significantly over time. Calcite and portlandite gain larger crystal size as maturation proceeded as well as ettringite.

The morphology of specimens over time, according to SEM, analysis is presented in Fig. 2. All S/S matrices represent systems suitable for "trapping" metals. The SEM results of the S/S indicated on a thick microstructure with hydration products, calcium silicate hydrate (C-S-H), calcium aluminate hydrate (C-A-H), gel flocculates. The C-A$\mathrm{S}-\mathrm{H}$ phases grow on Si-rich substrates and are accompanied by other secondary minerals such as carbonates (on the clay side) and ettringite (on the lime side) according to Fernandez et al. [19]. C-S-H possesses the sorption potential for metals due to its very large specific surface, which with its irregular hydrogen bonds can ease the sorption of water and other "foreign" ions, such as metal ions [46]. Both kaolinite and montmorillonite produce plaque structures. In the structure of montmorillonite, Al and $\mathrm{Si}$ are exposed to crystalline edges and partially hydrolyzed to silanol $(\mathrm{SiOH})$ and aluminum $(\mathrm{AlOH})$ groups. Such unsaturated edges are much more sensitive than saturated base sites [47]. This leads to the inner-sphere of
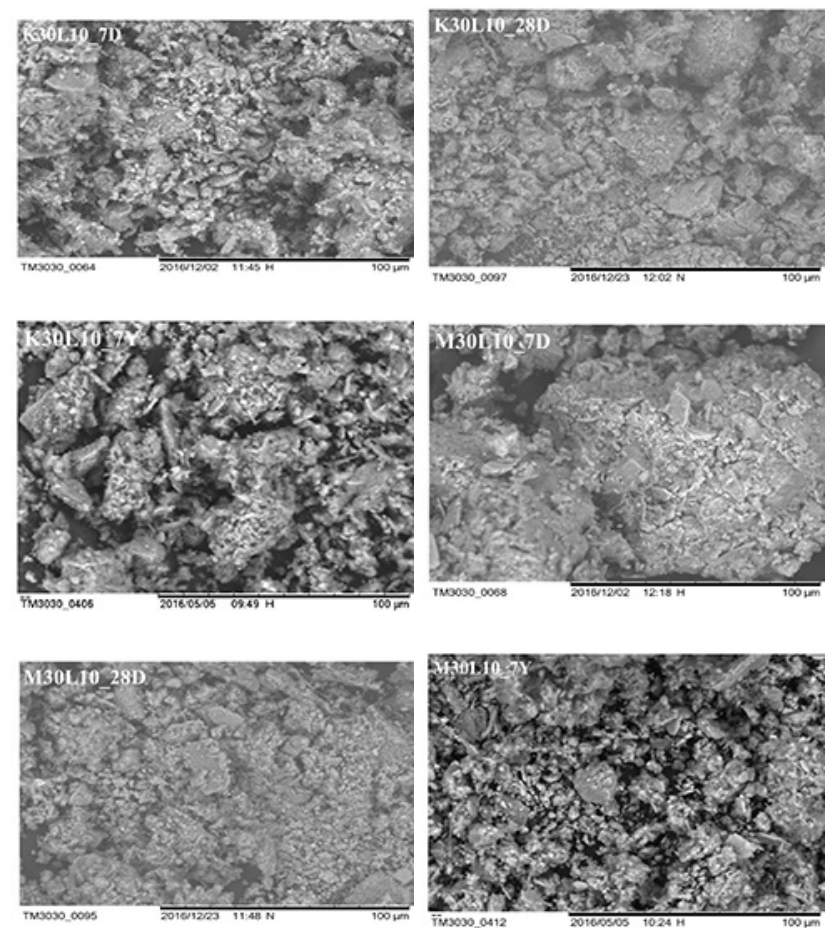

Fig. 2 The morphology of selected samples obtained by SEM analysis metal complexes and on planar (inner) locations of clay minerals, which causes the creation of an external sphere of metal complexes [48]. Generally, clay particles are strongly anisotropic and exhibit faces and edges, which are very different in surface area and in chemical behavior. A number of mechanisms have been supposed to be active in the sorption of heavy metals by these sorbents. Some of these mechanisms are chemisorption, physical adsorption and micro-precipitation which involve (i) an ion exchange reaction at permanent-charge sites and, (ii) formation of complexes with surface hydroxyl groups at edge-sites. Montmorillonite clay are commonly used as an effective leachate barrier of toxic heavy metal ions and radionuclides due to its good swelling property, high chemical/mechanical stability, high specific surface area and fine cation exchange capacity. Montmorillonite sorbs heavy metals both on planar sites with permanent charge on the interlayer surfaces and on edge sites with variable charge on the external surfaces. The sorption on planar sites is $\mathrm{pH}$-independent and is considered to be ion exchange reaction while that on edge sites is $\mathrm{pH}$-dependent and is thought to be complexation reaction. Kaolinite possesses a layered structure with a large surface area and high cationic exchange capacity. Kaolinite exhibited a strong affinity for both positive and negative heavy metal ions, whereas the sorption capacity for positive heavy metal ions was much higher than that for negative heavy metal ions because of the negative charge on the structure of clay. Metals tend to be adsorbed via ion exchange reaction over the acidic $\mathrm{pH}$ range and surface complexation over the near-neutral $\mathrm{pH}$ range. For example, the sorption mechanism for $\mathrm{Cu}(\mathrm{II})$ binding on montmorillonite over the alkaline $\mathrm{pH}$ range is significantly different from that for $\mathrm{Ni}(\mathrm{II})$. The adsorbed species for $\mathrm{Cu}(\mathrm{II})$ are identified as surface multinuclear complexes whereas that for $\mathrm{Ni}(\mathrm{II})$ are recognized as Ni phyllosilicate co-precipitate and/or nickel hydroxide precipitate. The distribution of sorbed heavy metals on planar and edge sites is controlled by many factors especially $\mathrm{pH}$ and the concentration of background electrolyte. A shift in heavy metal sorption from planar sites to edge sites can happen in response to an increase in both $\mathrm{pH}$ and electrolyte concentration [36, 49-51].

Specimens are characterized over time in terms of BET specific surface area and porosity. Results are presented in Table 7. Namely, the significant particle size effect is that the smaller particles have a larger surface that is available for hydration, which will cause the formation of more hydration products in the earlier stages of the $\mathrm{S} / \mathrm{S}$ treatment, 
Table 7 Surface area and pore analysis of specimens over time

\begin{tabular}{|c|c|c|c|c|c|c|c|c|c|c|}
\hline Parameter & Sediment & $\mathrm{K}$ & M & $\mathrm{L}$ & K30L10_7D & K30L10_28D & K30L10_7Y & M30L10_7D & M30L10_28D & M30L10_7Y \\
\hline $\operatorname{BET}\left(\mathrm{m}^{2} \mathrm{~g}^{-1}\right)$ & 17.999 & 10.322 & 85.359 & 4.895 & 9.233 & 10.053 & 8.553 & 9.741 & 25.384 & 8.752 \\
\hline $\begin{array}{l}\text { Mikropore } \\
\text { t-test }\left(\mathrm{cm}^{3} \mathrm{~g}^{-1}\right)\end{array}$ & 0.001 & nd & 0.021 & nd & nd & nd & nd & nd & 0,004 & nd \\
\hline $\begin{array}{l}\text { Mikropore HK } \\
\text { metod }\left(\mathrm{cm}^{3} \mathrm{~g}^{-1}\right)\end{array}$ & 0.007 & 0.004 & 0.036 & 0.002 & 0.004 & 0.004 & 0.0031 & 0.004 & 0.010 & 0.003 \\
\hline $\begin{array}{l}\text { BJH total pore } \\
\text { volume }\left(\mathrm{cm}^{3} \mathrm{~g}^{-1}\right)\end{array}$ & 0.062 & 0.134 & 0.103 & 0.063 & 0.097 & 0.096 & 0.112 & 0.067 & 0.075 & 0.096 \\
\hline $\begin{array}{l}\text { Average pore } \\
\text { radius }(\AA)\end{array}$ & 72.10 & 261.33 & 28.43 & 255.42 & 208.59 & 190.72 & 261.35 & 132.17 & 59.20 & 213.57 \\
\hline $\begin{array}{l}\text { Total pore } \\
\text { volume }\left(\mathrm{cm}^{3} \mathrm{~g}^{-1}\right)\end{array}$ & 0.065 & 0.135 & 0.121 & 0.063 & 0.096 & 0.096 & 0.112 & 0.064 & 0.075 & 0.093 \\
\hline
\end{tabular}

nd-not detected

resulting in better immobilization of the metal. In the early stage of the treatment (7 days), BET specific surface areas of specimens were similar due to immobilization agents mixing, compacting and pozzolanic reactions taking place.

After 28 days BET specific surface increased in both monoliths as a result of specimens maturing and hydration product formation, which are most intensified in this early stage of sample aging. This is especially noticeable in the case of M30L10_28D sample, where BET specific surface area almost tripled. After seven years a decrease in surface area is noticed. In this time period all the moisture evaporated from the samples. Also, it is assumed that all reaction terminated and a complete hardening and compaction of samples took place. Micropore volumes, according to HK method, changed in the same order, indicating on sample compaction and micropore closing over time. According to micropore t-test, micropores are detected in native sediment sample as well as in montmorillonite and M30L10_28D correlating well with the value of BET specific surface area. Mesopore volumes slightly increased in the period between 7 and 28 days, and then over longer period of time decreased and stabilized, representing good matrices for heavy metal entrapment. Average pore radius also indicates on predominant mesoporosity of all specimens as values for this parameter were in range of $20-500 \AA$. Also, obtained results are in compliance with metal leaching as aged specimens did not structurally deteriorate, in greater extent, over time, which is in good correlation with Wang et al. [52]. Treatments such as the Non-Local Density Functional Theory (NLDFT) provide a much more accurate approach for pore size analysis. This method bridge the gap between the molecular level and macroscopic approaches. Incremental and cumulative pore size distribution of different specimens determined by the NLDFT method is presented in Fig. 3 ((a) and (b)). The NLDFT model takes into account the differences in thermodynamic properties of a bulk fluid vs a fluid confined in pores. Thus it is able to give a more accurate description of the micro and mesopores [53]. All specimens showed significant pore volume resulting from mesopores fraction predominantly of $20,40,70,95$ and $140 \AA$
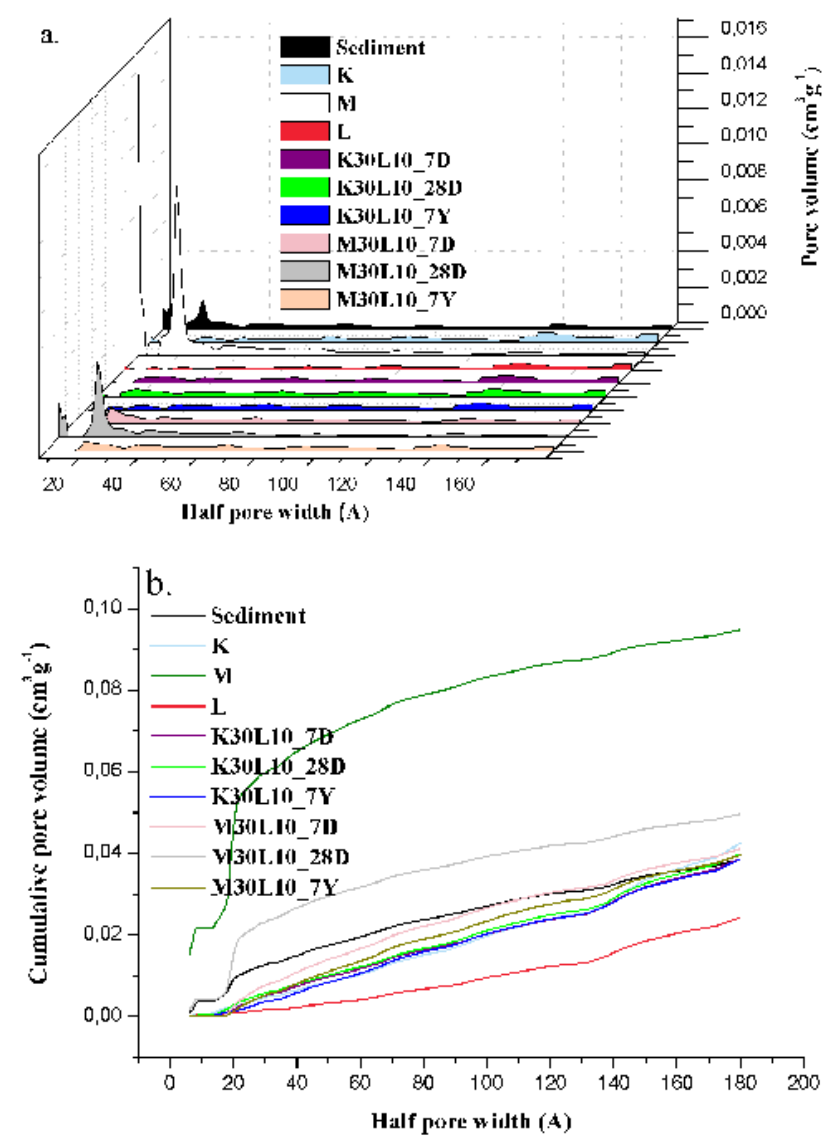

Fig. 3 (a) Incremental and (b) cumulative pore volume of different specimens as determined by the NLDFT method 
in half pore width. Native sediment, montmorillonite and M30L10 sample after 28 days showed more significant micropore content with half pore width $\leq 10 \AA$.

Unconfined compressive strength is used as a measure of the ability of a monolithic S/S material to resist mechanical stresses. It relates to the progress of hydration reactions in the product, and durability of a monolithic S/S material, and is therefore a key variable. The measurement results of unconfined compressive strength of tested $\mathrm{S} / \mathrm{S}$ mixtures are shown in Fig. 4. According to the EPA SW872 [54], S/S materials with hardness greater than $0.35 \mathrm{MPa}$ shall be considered to have sufficient compressive strength. This minimum value is proposed in order to create a stable foundation for the disposal of these materials in landfills. In the UK, acceptable strength after 28 days is $0.7 \mathrm{MPa}$, but the value of 0.35 is acceptable depending on the test sample [55]. According to ASTM C129, 2011 [31], compressive strength of M30L10_7Y exceeded 4.14 MPa, thus these blocks are potentially applicable as non-load-bearing concrete masonry units, such as partition walls, planting bricks, and landscaping walls, ground leveling/stabilization to the design formation level prior to construction works.

Alkali-enriched systems would dissolve siliceous components causing microcrack formation and/or result in a more compact C-S-H structure leading to higher porosity [52].

\section{Conclusion}

This objective of this study was assessing long-term performance of $\mathrm{S} / \mathrm{S}$ treatment of metal polluted sediment. Kaolinite, montmorillonite and lime were used as immobilization agents in $\mathrm{S} / \mathrm{S}$ treatment. Obtained samples were tested trough leaching tests, TCLP and DIN 3841-4 S4 procedure as well as trough mineralogical and structural characterization in different time periods after applied treatment (7, 28 days and 7 years). Leaching tests, differing in nature and $\mathrm{pH}$ of leaching fluid, indicated on successful S/S treatment as leached metal concentrations complied with the both acceptance criteria. Differences in leached concentrations over time are mostly attributed to $\mathrm{pH}$ variations and present crystals phases that may cause expansion and physical damage of monoliths. X-ray diffraction (XRD), qualitative and semi-quantitative analysis, confirmed the formation of hydration and pozzolanic product indicating that longer period of time is needed for final mineral composition to be formed. Semi-qualitative analysis indicated on increased content of hydratation product over time and crystallite size determination

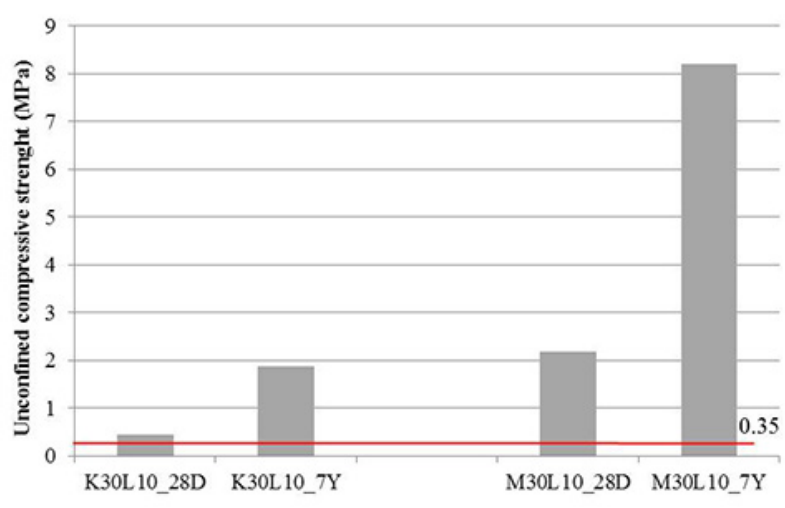

Fig. 4 Unconfined compressive strength (MPa) of obtained S/S mixtures after 28 days and 7 years

showed formation of smaller and finer crystals at longer time-scale. Scanning electron microscope (SEM) analysis confirmed that morphology of tested specimens represents viable matrices for entrapment of metals creating dense structures over time. Porosity and pore size distribution measurements indicated that specimens represent mesoporous structures, closing micropores and mesopores over time due to moisture evaporation and gradual compaction. Notable presence of micropores is detected in matrices containing montmorillonite. Unconfined compressive strength indicated on ability to create a stable foundation for the disposal of these materials in landfills. Aged sample with $30 \%$ montmorillonite and $10 \%$ of lime proved to be potentially applicable as non-load-bearing concrete masonry units, viable for controlled utilization. Generally, all results indicated on successful treatment with undiminished efficiency over a period of several years indicating that this represents reliable, environmentally friendly and cost-effective remediation technique.

\section{Acknowledgement}

This work has been produced with the financial assistance of the Ministry of Education, Science and Technological Development of the Republic of Serbia (III43005 and TR37004) and Provincial Secretariat for Higher Education and Scientific Research, AP Vojvodina (project No.142-4512451/2018-01/02). The authors would like to thank BioSense Institute from Novi Sad, Serbia, for the use of measurement equipment and data analysis as well as to Goran Kitic, $\mathrm{PhD}$ for his dedicated support and assistance. Also authors would like to thank Prof. Srdjan Rakic, Department of physics, Faculty of Sciences, Novi Sad for his assistance in performing X-ray diffraction measurements. 


\section{References}

[1] Pereira C., F., Rodriguez-Pinero, M., Vale, J. "Solidification/stabilization of electric arc furnace dust using coal fly ash: analysis of the stabilization process", Journal of Hazardous Materials, 82(2), pp. 183-195, 2001.

https://doi.org/10.1016/S0304-3894(00)00359-9

[2] Tomasevic, D. D., Dalmacija, M. B., Prica, M. D.,Dalmacija, B. D., Kerkez, D. V., Becelic-Tomin, M. R., Roncevic, S. D. "Use of fly ash for remediation of metals polluted sediment - Green remediation", Chemosphere, 92(11), pp. 1490-1497, 2013.

https://doi.org/10.1016/j.chemosphere.2013.03.063

[3] Wang, L., Tsang, D. C. W., Poon, C. S. "Green remediation and recycling of contaminated sediment by waste-incorporated stabilization/solidification", Chemosphere, 122, pp. 257-264, 2015.

https://doi.org/10.1016/j.chemosphere.2014.11.071

[4] Wen, J., Yi, Y., Zeng, G. "Effects of modified zeolite on the removal and stabilization of heavy metals in contaminated lake sediment using BCR sequential extraction", Journal of Environmental Management, 178, pp. 63-69, 2016.

https://doi.org/10.1016/j.jenvman.2016.04.046

[5] Yu, K., Xu, J., Jiang, X., Liu, C., McCall, W., Lu, J. "Stabilization of heavy metals in soil using two organo-bentonites", Chemosphere, 184, pp. 884-891, 2017.

https://doi.org/10.1016/j.chemosphere.2017.06.040

[6] Liu, J., Zha, F., Xu, L., Yang, C., Chu, C., Tan, X. "Effect of chloride attack on strength and leaching properties of solidified/stabilized heavy metal contaminated soils", Engineering Geology, 246, pp. $28-35,2018$.

https://doi.org/10.1016/j.enggeo.2018.09.017

[7] Singh, T. S., Pant, K. K. "Solidification/stabilization of arsenic containing solidwastes using portland cement, fly ash and polymeric materials", Journal of Hazardous Materials, 131(1-3), pp. 29-36, 2006.

https://doi.org/10.1016/j.jhazmat.2005.06.046

[8] Feigl, V., Gruiz, K., Anton, A. "Remediation of metal ore mine waste using combined chemical- and phytostabilisation", PeriodicaPolytechnica Chemical Engineering, 54(2), pp. 71-80, 2010.

https://doi.org/10.3311/pp.ch.2010-2.03

[9] Kogbara, R.B., Al-Tabbaa, A. "Mechanical and leaching behaviour of slag-cement and lime-activated slag stabilised/solidified contaminated soil", Science of the Total Environment, 409(11), pp. $2325-2335,2011$.

https://doi.org/10.1016/j.scitotenv.2011.02.037

[10] Dohnálková, B., Drochytka, R., Hodul, J. "New possibilities of neutralisation sludge solidification technology", Journal of Cleaner Production, 204, pp. 1097-1107, 2018.

https://doi.org/10.1016/j.jclepro.2018.08.095

[11] Dermatas, D., Moon, D. H., Menounou, N., Meng, X., Hires, R. "An evaluation of arsenic release from monolithic solids using a modified semi-dynamic leaching test", Journal of Hazardous Materials, 116(1-2), pp. 25-38, 2004. https://doi.org/10.1016/j.jhazmat.2004.04.023
[12] Moon, D. H., Dermatas D. "Arsenic and lead release from fly ash stabilized/solidified soils under modified semi-dynamic leaching conditions", Journal of Hazardous Materials, 141(2), pp. 388-394, 2007.

https://doi.org/10.1016/j.jhazmat.2006.05.085

[13] Bhattacharyya, K. G., Gupta, S. S. "Adsorption of chromium (VI) from water by clays", Industrial \& Engineering Chemistry Research, 45(21), pp. 7232-7240, 2006. https://doi.org/10.1021/ie060586j

[14] Bhattacharyya, K. G., Gupta, S. S. "Adsorption of a few heavy metals on natural and modified kaolinite and montmorillonite: A review", Advances in Colloid and Interface Science, 140(2), pp. 114-131, 2008.

https://doi.org/10.1016/j.cis.2007.12.008

[15] Matusik, J., Matykowska, L. "Behaviour of kaolinite intercalation compounds with selected ammonium salts in aqueous chromate and arsenate solutions", Journal of Molecular Structure, 1071, pp. 52-59, 2014. https://doi.org/10.1016/j.molstruc.2014.04.063

[16] Zsirka, B., Horváth, E., Makó, É., Kurdi, R., Kristóf, J. "Preparation and characterization of kaolinite nanostructures: reaction pathways, morphology and structural order", Clay Minerals, 50(3), pp. 329-340, 2015. https://doi.org/10.1180/claymin.2015.050.3.06

[17] Wang, F., Wang, H., Al-Tabbaa, A. "Leachability and heavy metal speciation of 17-year old stabilised/solidified contaminated site soils", Journal of Hazardous Materials, 278, pp. 144-151, 2014. https://doi.org/10.1016/j.jhazmat.2014.05.102

[18] Savage, D., Walker, C., Arthur, R., Rochelle, C., Oda, C., Takase, H. "Alteration of bentonite by hyperalkaline fluids: A review of the role of secondary minerals", Physics and Chemistry of the Earth, Parts A/B/C, 32(1-7), pp. 287-297, 2007. https://doi.org/10.1016/j.pce.2005.08.048

[19] Fernández, R., Ruiz, A. I., Cuevas, J. "Formation of C-A-S-H phases from the interaction between concrete or cement and bentonite", Clay Minerals, 51(2), pp. 223-235, 2015.

https://oi.org/10.1180/claymin.2016.051.2.09

[20] Dalmacija, M., Prica, M., Dalmacija, B., Roncevic, S., Klasnja, M. "Quantifying the environmental impact of As and Cr in stabilized/ solidified materials", Science of the Total Environment, 412-413, pp. 366-374, 2011.

https://oi.org/10.1016/j.scitotenv.2011.10.006

[21] USEPA Method 3051a "Microwave assisted acid digestion of sediments, sludges, soils and oils", Revision 1, United States Environmental Protection Agency, Washington DC, USA, 2007.

[22] USEPA Method 7000B "Flame atomic absorption spectrophotometry", Revision 2, United States Environmental Protection Agency, Washington DC, USA, 2007.

[23] Memoli, V., Eymar, E., García-Delgado, C., Esposito, F., Santorufo, L., De Marco, A., Barile, R., Maisto, G. "Total and fraction content of elements in volcanic soil: Natural or anthropogenic derivation", Science of the Total Environment, 625, pp. 16-26, 2018. https://doi.org/10.1016/j.scitotenv.2017.12.223 
[24] Official Gazette RS "50/2012 Regulation on Limit Values of Pollutants in Surface and Groundwater and sediment and deadlines for their achievement", Official Gazette of the Republic of Serbia, Belgrade, 2012.

[25] ASTM D1557-00 "Standard test method for laboratory compaction characteristics of soil using modified effort American Society for Testing Materials", Annual Book of ASTM standards: ASTM D1557-91, vol. 4.08, ASTM International, Philadelphia USA, 2000.

[26] USEPA "Toxicity characteristic leaching procedure, method 1311", United States Environmental Protection Agency, Washington DC, USA, 2002. [online] Available at: www.EPA.gov/SW-846/1311.pdf [Accessed: 12 February 2018]

[27] USEPA "Method 7010 Graphite Furnace Absorption Spectrophotometry", Revision 0, United States Environmental Protection Agency, Washington DC, USA, 2007.

[28] DIN 38414-4 "Schlamm und Sedimente, Gruppe S., Bestimmung der EluierbarkeitmitWasser S4" (German standard methods for the examination of water, waste water and sludge; sludge and sediments (group S); determination of leachability by water (S4)), BeuthVerlag, Berlin, Germany, 1984.

[29] Patel, H., Pandey, S. "Evaluation of physical stability and leachability of Portland Pozzolona Cement (PPC) solidified chemical sludge generated from textile wastewater treatment plants", Journal of Hazardous Materials, 207-208, pp. 56-64, 2012. https://doi.org/10.1016/j.jhazmat.2011.05.028

[30] del Valle-Zermeño, R., Formosa, J., Chimenos, J. M., Martínez, M., Fernández, A. I. "Aggregate material formulated with MSWI bottom ash and APC fly ash for use as secondary building material", Waste Management, 33(3), pp. 621-627, 2013. https://doi.org/10.1016/j.wasman.2012.09.015

[31] ASTM "Strength Specification for Non-Load-Bearing Concrete Masonry Units. ASTM Standard C129", ASTM International, West Conshohocken USA, 2011. http://doi.org/10.1520/C0129-11

[32] ASTM "Strength Specification for Load-Bearing Concrete Masonry Units. ASTM Standard C90", ASTM International, West Conshohocken USA, 2014. http://doi.org/10.1520/C0090

[33] Official Gazette 56/2010 "The Ministry of Energy, Development and the Environment, Regulation on categories, testing and classification of waste", Official Gazette of the Republic of Serbia, Belgrade, 2010.

[34] Council Decision 2003/33/EC, 19 December 2002, Official Journal of the European Communities, L11, of establishing criteria and procedures for the acceptance of waste at landfills

[35] Townsend, T., Tolaymat, T., Solo-Gabriele, H., Dubey, B., Stook, K., Wadanambi, L. "Leaching of CCA-treated wood: implications for waste disposal", Journal of Hazardous Materials, 114(13), pp. 75-91, 2004.

https://doi.org/10.1016/j.jhazmat.2004.06.025

[36] Ijagbemi, C. O., Baek, M.H., Kim, D. S. "Montmorillonite surface properties and sorption characteristics for heavy metal removal from aqueous solutions", Journal of Hazardous Materials, 166(1), pp. 538-546, 2009.

https://doi.org/10.1016/j.jhazmat.2008.11.085
[37] Lu, C. C., Hsu, M. H., Lin, Y. P. "Evaluation of heavy metal leachability of incinerating recycled aggregate and solidification/stabilization products for construction reuse using TCLP, multi-final $\mathrm{pH}$ and EDTA-mediated TCLP leaching tests", Journal of Hazardous Materials, 368, pp. 336-344, 2019.

https://doi.org/10.1016/j.jhazmat.2019.01.066

[38] Suponik, T. "Ensuring permeable reactive barrier efficacy and longevity", Archives of Environmental Protection, 36, pp. 59-73, 2010. [online] Available at: http://journals.pan.pl/dlibra/journal/96938 [Accessed: 23 January 2018]

[39] Spence, R. D., Shi, C. "Stabilization and solidification of hazardous, radioactive and mixed wastes", CRC Press, Boca-Raton London, UK, 2005.

[40] Antemira, A., Hills, C. D., Careya, P. J., Gardnerb, K. H., Batesc, E. R., Crumbied, A. K. "Long-term performance of aged waste forms treated by stabilization/solidification", Journal of Hazardous Materials, 181(1-3), pp. 65-73, 2010. https://doi.org/10.1016/j.jhazmat.2010.04.082

[41] Al-Tabbaa, A., Boes N. "Pilot in situ auger mixing treatment of a contaminated site: Part 4. Performance at five years", Proceedings of the Institution of Civil Engineers - Geotechnical Engineering, 155(3), pp. 187-202, 2002.

https://doi.org/10.1680/geng.2002.155.3.187

[42] Chen, Q., Hills, C. D., Yuan, M., Liu, H., Tyrer, M. "Characterization of carbonated tricalcium silicate and its sorption capacity for heavy metals: A micron-scale composite adsorbent of active silicate gel and calcite", Journal of Hazardous Materials, 153(1-2), pp. 775-783, 2008. https://doi.org/10.1016/j.jhazmat.2007.09.023

[43] Thiebaut, Y.,Multon, S., Sellier, A., Lacarrière L., Boutillon, L., Belili, D., Linger, L., Cussigh, F., Hadji, S. "Effects of stress on concrete expansion due to delayed ettringite formation", Construction and Building Materials, 183, pp. 626-641, 2018. https://doi.org/10.1016/j.conbuildmat.2018.06.172

[44] Nowak, S., Lafon, S., Caquineau, S., Journet, E., Laurent, B. "Quantitative study of the mineralogical composition of mineral dust aerosols by X-ray diffraction", Talanta, 186, pp. 133-139, 2018. https://doi.org/10.1016/j.talanta.2018.03.059

[45] Burton, A. W., Ong, K., Rea, T., Chan, I. Y. "On the estimation of average crystallite size of zeolites from the Scherrer equation: A critical evaluation of its application to zeolites with one-dimensional pore systems", Microporous and Mesoporous Materials, 117(1-2), pp. 75-90, 2009. https://doi.org/10.1016/j.micromeso.2008.06.010

[46] Xiaolu, G., Huisheng, S., Warren, A. D. "Compressive strength and microstructural characteristics of class C fly ash geopolymer", Cement and Concrete Composites, 32(2), pp. 142-147, 2010. https://doi.org/10.1016/j.cemconcomp.2009.11.003

[47] Hennig, C., Reich, T., Dahn, R., Scheidegger, A. M. "Structure of uranium sorption complexes at montmorillonite edge sites", Radiochimica Acta, 90(9-11), pp. 653-657, 2002. https://doi.org/10.1524/ract.2002.90.9-11_2002.653

[48] Elzinga, E. J., Sparks, D. L. "Nickel Sorption Mechanisms in a Pyrophyllite Montmorillonite Mixture", Journal of Colloid and Interface Science, 213(2), pp. 506-512, 1999. https://doi.org/10.1006/jcis.1999.6161 
[49] Zhu, J., Cozzolino, V., Pigna, M., Huang, Q., Caporale, A. G., Violante, $\mathrm{A}$. "Sorption of $\mathrm{Cu}, \mathrm{Pb}$ and $\mathrm{Cr}$ on Na-montmorillonite: Competition and effect of major elements", Chemosphere, 84(4), pp. 484-489, 2011.

https://doi.org/10.1016/j.chemosphere.2011.03.020

[50] Yang, S., Ren, X., Zhao, G., Shi, W., Montavon, G., Grambow, B., Wang, $\mathrm{X}$. "Competitive sorption and selective sequence of $\mathrm{Cu}(\mathrm{II})$ and $\mathrm{Ni}(\mathrm{II})$ on montmorillonite: Batch, modeling, EPR and XAS studies", Geochimica et Cosmochimica Acta, 166, pp. 129-145, 2015.

https://doi.org/10.1016/j.gca.2015.06.020

[51] He, G., Wang, C., Cao, J., Fan, I., Zhao, S., Chai, Y. "Carboxymethyl chitosan-kaolinite composite hydrogel for efficient copper ions trapping", Journal of Environmental Chemical Engineering, 7(2) ID: 102953, 2019. https://doi.org/10.1016/j.jece.2019.102953

[52] Wang, L., Kwok, J. S., Tsang, D. C., Poon, C. S. "Mixture design and treatment methods for recycling contaminated sediment", Journal of Hazardous Materials, 283, pp. 623-632, 2015. https://doi.org/10.1016/j.jhazmat.2014.09.056
[53] Kumara, P. S., Korving, L., Keesman, K. J., van Loosdrecht, M. C. M., Witkamp, G. J. "Effect of pore size distribution and particle size of porous metal oxides on phosphate adsorption capacity and kinetics", Chemical Engineering Journal, 358, pp. 160-169, 2019. https://doi.org/10.1016/j.cej.2018.09.202

[54] EPA SW872 "Guide to disposal of chemically stabilized and solidified wastes", United States Environmental Protection Agency, Washington DC, USA, 1982.

[55] Hills, C. D., Pollard, S. J. T. "Influence of interferences effect on the mechanical, microstructural and fixation characteristics of cement solidified hazardous waste forms", Journal of Hazardous Materials, 52(2-3), pp. 171-191, 1997. https://doi.org/10.1016/S0304-3894(96)01806-7 